\title{
Inserting Spoken Language in Grammar Teaching Material Based on Interactive Multimedia
}

\author{
Yuli Tiarina \\ Doctorate Students of Post Graduate \\ Universitas Negeri Padang \\ Padang, Indonesia \\ yulitiarina@yahoo.co.id \\ Jufrizal \\ Universitas Negeri Padang \\ Jl. Prof. Dr. Hamka, Padang, Indonesia
}

\author{
Hermawati Syarif \\ Universitas Negeri Padang \\ Jl. Prof. Dr. Hamka, Padang, Indonesia \\ Yenni Rozimela \\ Universitas Negeri Padang \\ Jl. Prof. Dr. Hamka, Padang, Indonesia
}

\begin{abstract}
Despite of asking whether to teach grammar or not, this article, a part of dissertation entitled Developing Basic English Grammar Teaching Material based on Interactive Multimedia at University Level, presents optional conditions for over teaching of grammar in digital era. Since effective teaching material should be authentic, and nowadays be based on technology, lecturers need to design a teaching material for grammar by inserting spoken language based on interactive multimedia, promoting effective grammar teaching learning, high grammar mastery and motivation. Therefore, the purposes of this descriptive research are to find out the kinds of exercises given by the lecturers of English Department of Universitas Negeri Padang (UNP), and to find out the innovative model of communicative and contextual exercises. This research uses qualitative approach. This research was carried out at English Department of Universitas Negeri Padang. Seven lecturers were involved as participants. The data were collected through questionnaire consisted of $\mathbf{1 6}$ items about kinds or exercises given to the students, and 3 questions about media for the exercises. The participants were asked to choose how often they gave any kind of exercises. The first finding is there were 2 kinds of exercises always given by the lecturers, 9 kinds of exercises often given by the lectures, and 5 kinds of exercises sometimes given by the lecturers. All the exercises are in written form. The second finding is the innovative model of communicative and contextual exercises is by inserting spoken language based on interactive multimedia. The source of the exercise is video podcast. The two types of exercises are identifying the part of speech and producing the part of speech. In conclusion, inserting spoken language based on interactive multimedia can promote the students accuracy and fluency on grammar. Further research is needed to see the effect of inserting spoken language based on interactive multimedia on students' grammar mastery.
\end{abstract}

Keywords-grammar; spoken language; teaching material; interactive multimedia

\section{INTRODUCTION}

Still a question about whether to teach grammar or not remains. One thing for sure is grammar as a component of language that supports the skills of language. Fluent grammar influences the comprehension in reading and in listening. Accurate grammar promotes high fluency in speaking and writing. Therefore instead of asking whether to teach grammar or not, as pointed by Brown (2001), it is better to find the solution for overt teaching grammar. One of the solutions is to have an authentic teaching material for grammar.

To have an authentic grammar teaching material, a lecturer can insert spoken language in teaching material. Learning about characteristics of grammar in spoken language can improve learners' fluency and face-to-face conversation, and prevents students from speaking like a textbook (Hilliard, 2014). Besides, inserting spoken language can lower the inconsistencies between the prescriptive grammar presented in EFL textbooks and the type of grammar used in the speech of native speakers (Al-wossabi, 2014). A number of studies point out the artificiality of textbook dialogues and highlight the need to develop and analyze larger corpora of spoken data to be used in the language classroom (Al-wossabi, 2014; Leech G. , 200; Ruhlemann, 2008). Both Al-wossabi (2014) and Hilliard (2014) propose the incoparation of spoken language into curricula for English learners. Further, Hilliard (2014) argues that the learners must be exposed to spoken dialogues - whether they are authentic or specially constructed - that include common features of spoken grammar that are so often missing in ELT textbooks. She suggests that teachers need to supply the textbook activities with authentic video, radio, and other audio materials to expose students to elements of spoken language. The suggestion from Hilliard brings us to the need of using interactive multimedia.

In this digital era, lecturers cannot count on the textbooks only. They need to utilize technology in teaching grammar. An interactive multimedia can be outstanding media based on technology that can promote students grammar mastery and motivation. Numerous researchers (Ampa, 2015; Jingjit, 2015; Liu, 2010; Mayer \& Moreno, 2002; Refnaldi, Ardi, \& Tiarina, 2010; Siskos \& Antoniou, 2005) have highlighted that interactive multimedia can nourish students comprehension and motivation in learning English or others. Related to grammar which is full of rules, interactive multimedia can increase students' memory (Mayer R. E., 2001). Based on the interview to some students of English Department of Universitas Negeri Padang (UNP), the students often forget 
the rules or form of grammar they have studied.

The problem under investigation in this study is that while some researchers noted the need to incorporate spoken language in EFL/ELT textbooks and found out the effectiveness of interactive multimedia, none is about inserting spoken language in teaching material based on interactive multimedia. Regarding the aforementioned research problem, the purpose of the present study is to investigate the types of exercises used by the grammar lecturers in the classroom and to promote the model of teaching material based on interactive multimedia by inserting spoken language.

There is a contention between prescriptive grammarians and descriptive grammarians. Honda \& O'Neil (2008, p. 2) highlight that "Prescriptive grammarians are judgmental and attempt to change linguistic behavior of a particular sort and in a particular direction. Linguists, or mental grammarians (Descriptive), on the other hand, seek to explain the knowledge of language that guide s people every day use of language regardless of their schooling" Al-wossabi (2014) provides the example for the use of ain't. For prescriptivists ain't should be avoided while for descriptive such usage can be accepted. To mediate the contention, pedagogical grammar can be used in teaching grammar in EFL classroom (Chalker, 1994). Pedagogical grammar talks about how to use language (spoken) and about language (written). As a result, Alwossabi (Spoken grammar: An urgent necessity in the EFL context, 2014) proposes the use of a balanced formalfunctional approach for teaching spoken and written grammar to EFL learners.

Before we go on to consideration of a balanced formalfunctional approach for teaching spoken and written grammar to EFL learners, it is better to talk about what spoken language is. The simplest definition of spoken language is a language used in conversation. The complete one from (Horowitz \& Samuels, 1987, p. 56) is "Oral language is typically associated by linguists with conversation that is produced, processed, and then evaluated in the context of face-to-face exchange and grounded in interpersonal relationships that are often clearly established. Oral language is adapted to a specific audience and to socio-cultural settings and communities that are presumably present, functioning in a context of here and now."

The above definition leads us to four main features of spoken language taken from Carter \& McCarthy (1995). “ Spoken language happens in real time and typically unplanned. Spoken language is most typically face-to-face. Spoken language foregrounds choices which reflect the immediate social and interpersonal situation. Spoken language and written language are not sharply divided but exist in continuum". Spoken language is of course constructed from grammar, called spoken grammar. Recognizing the classroom role of spoken grammar is more important nowadays (Hilliard, 2014). Further, she summarizes the features of grammar in spoken language into six. Firts, spoken language has ellipsis. Although ellipsis is found in both spoken and written English, situational ellipsis, such as "sounds good" and "absolutely right", often happens in spoken language. Second, spoken language uses heads allowing the speaker to point out the topic. The example of the utterance with head is "The soccer game last night, it was really exciting". Third, spoken language has tails. Tails are comments added to the end of a pharse. For example, the uttence "My teacher is really nice, the one from America.' has tail "the one from America. Fourth, spoken language has fillers and backchanels. Fillers are words and utternaces filling time and allowing the speaker to gather his or hen thought (Willis D. , 2003). The example of fillers are "er", "well", "hmm", and "um". Meanwhile, backchannels are words and utterances like "uh-huh", "oh", "yeah", and "I see" used to articulate what the speaker is saying and encourage him/her to continue (Stenstrom, 2004). Fifth, spoken language uses ready-made chunks. Chunks are automatically produce strings or words or utterance used repeatedly (McCarty \& O'Keeffe, 2014). Taken from Hilliard (2014), there are three functions of chunks, namely to create vagueness (e.g., "sort of', "kind of", and "stuff like that"), modify and show politeness (e.g., "a bit", and "a little bit"), and mark discourse structure (e.g., "You know", "I mean", "I guess", and "I think").

Let's come back to consideration of a balanced formalfunctional approach for teaching spoken and written grammar to EFL learners. Al-wossabi (2014) suggests the consideration based on his real teaching practices of spoken English in EFL grammar classes.

1) Spoken and written grammatical presentations necessitate specific grouping when integrated in L2 grammar textbooks. For example, spoken grammar presentation can be labeled under the name of Spoken Form while written grammar presentation can take the name of General Form as they can be used for both written and formal spoken purposes.

2) Spoken form presentation should not be equally aligned and weighted to that of the Written Form presentation which EFL learners have been familiar with for at least six years of their previous education. It is preferred, then, that the Spoken Form presentation is placed at the end section in each lesson whether in pure L2 grammar textbook or in integrated skill textbooks.

3) The written form section should be introduced to students as it used be presented in their EFL grammar books, as we do not want to create a type of conflict and resistance among learners to the new learning items and /or the previous learnt items.

4) Learning and practicing spoken/written structures should be separated when FIRST introduced as long as it is clear for learners that each structure serves a different purpose.

5) Integrated learning activities of both forms can be used at the end of the lesson for the sake of recognizing the different linguistic structures being learnt.

6) Examples of conversational grammar should be simple and appealing for learners. Learners are not to be 
overwhelmed with ambiguous vernacular speech. The overall goal is to help EFL learners produce intelligible output.

7) Authentic listening exercises pertaining conversational grammar structures should be an integral part of the syllabus. Listening to authentic extracts from everyday English will reinforce the learners' recognition of the features of naturally occurring speech and might lead to internalization.

8) EFL experts and language teachers should be consulted and involved in the process of tailoring spoken grammar structures in L2 teaching materials.

Al-wosaabi (2014), Hilliard (2014) and McCarthy \& O'Keefee (2014) suggested the lecturers to use spoken English in classroom activities. McCarthy \& O'Keefee offer three activities for ellipsis. First, given real recorded conversations or email, the students are asked to change the conversations or email into complete sentences. Second, given some formal (complete sentences), the students' change them into informal ones (see more activities in McCarthy \& O'Keefee, 2014). Meanwhile, Hilliard proposed spoken English activities for ellipsis such as ellipsis in video, long and short version of conversation, and ellipsis game (see more activities in Hilliard, 2014).

The above considerations can be adopted in promoting model of teaching material. However, some points should be added in order to make the innovative model. Because of current trends emphasizing digital, using technology must become one of other considerations. Listening to authentic listening exercises is not enough. For innovative consideration, interactive multimedia is needed.

Interactive multimedia is an integration between texts, audio and visual (Costello, Youngblood, \& Youngblood, 2012; Ivers \& Barron, 2010; Li \& Drew, 2004; Mayer R. E., 2005; Newby, Stepich, Lehman, \& Russell, 2000; Roblyer \& Doering, 2010; Simkins, Cole, Tavalin, \& Means, 2002; Smaldino, Russell, Heinich, \& Molenda, 2014; Solomon, 2011) in which the users can control what they want (Phillips, 1997; Schwier \& Misanchuk, 1993). Using film or video as a source of teaching can provide a visual material together with text and audio. Joshi (2012) gives deep description using multimedia in the classroom. She discussed that besides providing a visual material, watching film or video can make the students fully understand both visual and verbal comprehension. Different from McCarthy \& O'Keefee who trains students in written form only and Hilliard who trains the students spoken English by watching the video, listening to the dialogue and crossing the missing words, the model proposed in this article will add an activity where students can produce the spoken language.

\section{METHOD}

This research uses qualitative approach. This research was carried out at English Department of Universitas Negeri Padang. Seven lecturers were involved as participants. The data were collected through questionnaire consisted of 16 items about kinds or exercises given to the students, and 3 questions about media for the exercises. The participants were asked to choose how often they gave any kinds of exercises. There were four choices, namely never, sometimes, often and always. Their choices were scored 1 for never, 2 for sometimes, 3 for often and 4 for always. The mean score for each item was calculated from total score divided by seven. Finally, the mean score for each item was converted and interpreted into four criteria as following table.

TABLE I. CRITERIA FOR KINDS OF EXERCISES GIVEN BY THE LECTURERS

\begin{tabular}{|c|l|l|}
\hline Number & \multicolumn{1}{|c|}{ Mean Score } & \multicolumn{1}{|c|}{ Criteria } \\
\hline 1 & $0.00-1.00$ & Never \\
\hline 2 & $1.01-2.00$ & Sometimes \\
\hline 3 & $2.01-3.00$ & Often \\
\hline 4 & $3.01-4.00$ & Always \\
\hline
\end{tabular}

\section{RESUlt AND Discussion}

The results of the analysis will be presented into two parts and followed by discussion of each. First, the frequency of kinds of exercises and media for exercises given to the students is depicted to hightligt the real condition of kinds exercises given to the students. Second, based on the real condition and considerations proposed by Al-wossabi and Hilliard, a model for an unthentic exercises will be designed.

\section{A. Kinds of Exercises Given to the Students}

It was found that there were 2 kinds of exercises always given by the lecturers, 9 kinds of exercises often given by the lectures, and 5 kinds of exercises sometimes given by the lecturers.

\section{1) The kinds of Exercises always given by the Lecturers}

The two kinds of exercises always given by the lecturers were error analysis (3.58) and asking the students to make their own sentences with the newly learned grammatical features (3.43). Among seven lecturers, four of them (57.14\%) always give error analysis, and the rest often give error analysis (42.86\%). There is a tendency that the lecturers asked the students to find the error of the sentences. Given to sentences, the students found the error and made the correct ones. Asking the students to make their own sentences with newly learned grammar features and with learned grammar were always done by three lecturers $(42.86 \%)$. Meanwhile, four lecturers often $(57.14 \%)$ asked the students to make their own sentences with the newly learned grammatical features.

\section{2) The kinds of Exercises often given by the Lecturers}

The nine kinds of exercises often given were completing sentences with grammar features (2.86), arranging words into correct sentences (2.71), choosing one of the right answers/multiple choice (2.86), making conversations with newly learned topic (2.43), making conversations and presenting them in class (2.71), making conversations and presenting them through social media (2.43), making 
sentences with newly learned grammar features (2.43), writing short paragraphs/text with newly learned grammatical features (2.57), and writing short paragraphs / text with newly learned grammar features and with previously learned grammatical features (2.57).

\section{3) The kinds of Exercises sometimes given by the Lecturers}

The exercises sometimes given were writing short paragraphs / texts with newly learned grammar features and previously learned grammatical features and then presenting them in social media (1.71), using interactive games, such as dual game (1.57), hangman game (1.29), snake and ladder game (1.43) and sequencing game (1.57).

\section{4) Media for the Exercise}

There are 3 findings. First, it was found that the lecturers sometimes gave the exercises orally in audio form (1.29). In detail, six lecturers $(85.71 \%)$ never gave the exercises orally in audio form, while one lecturers (14.29\%). Second, it was found that the lecturers sometimes gave the exercises orally in audio and visual form (1.29). In detail, four lecturers (57.145) never gave the exercises orally in audio and visual form; two lecturers $(28.57 \%)$ sometimes the exercises orally in audio and visual form; one lecturer (14.29) often the exercises orally in audio and visual form. The last, it was found that the lecturers sometimes gave the exercises through multimedia (1.86). In detail, three lecturers $(42.86 \%)$ never gave the exercises gave the exercises through multimedia; two lecturers $(28.57 \%)$ sometimes gave the exercises through multimedia; two lecturers $(28.57 \%)$ often gave the exercises through multimedia.

The findings above shows that the lecturer have successfully asked the students to use the grammar they learn in written forms. Refnita (2012) highligted that asking the students to use grammar in their own writing is effective to improve their writing skill. However, asking the students to use grammar in written form only is not enough yet since, based on the grammar sillaby at English Department UNP, the objectives of teaching grammar is the students are able to use grammar in written and oral forms. The tendency of the lecturers to focus on written form only can be because they rely on the text book. The lecturers of English Department of UNP still use a text book for teaching grammar. In fact, conventional teaching and learning methods that rely on books and lectures do not guarantee the effectiveness of teaching and learning process (Herrington \& Herrington, 1998). As it is found that the text book used at present is not supported by communicative and contextual exercises, and even some topic are not provided with exercises (Tiarina, 2017).

The finding also reflects that the lecturers have not used technology yet, especially multimedia. It is in line with a research conducted by Hamzah, Rinaldi \& Razak (2014). They found that the multimedia usage among lecturers was moderate. There might be reasons for the lecturers not using multimedia. First, it could be because of the difficulty to access for relevant materials and the significant amount of time that must be provided in the preparation (Ely, 1990).
Yalcin et al. (2011) also found that lecturers need time to understand and use the technology effectively. They have no enough time because of coursework and assignments. The workload had caused significantly on the use of multimedia (Hamzah, Rinaldi, \& Razak, 2014). Something needs to be done to hep the lecturers in order to provide the exercises that can make the studets able to use grammar in written and oral forms and make use of technology, multimedia. It brings us to a model of authentic exercises.

\section{B. Inserting Spoken Language in Classroom Exercises}

This parts will propose a model of inserting spoken language in Basic English Grammar teaching material based on interactive multimedia. The model will adapt some considerations of teaching spoken English from Al-wossabi (2014), and modify the activities from Hilliard (2014) and McCarthy and O'Keeffe (2014). First, in line with Al-wossabi (2014), students will notice and learn spoken language at the end of the lesson. It will become the last activities for one grammar lesson. In this model, the topic will be about the part of speech (based on the syllabi of English Department of UNP). The organization of the teaching material is time to watch, time to chat, time to focus, time for fun, time to practice, time for action (see Tiarina, 2017). Time for action is a time or chance for the students to produce learnt grammatical features in written and oral forms. Second, similar to Hilliard (2014), an authentic video will be taken from Luke's English Podcast, http://teacherluke.co.uk/2010/03/26/116) uploaded in YouTube. Third, different from Hilliard, the activities from this model will be interactive. The students will get direct feedback of their answers. The students can do the activities out of the class room, anywhere and anytime. Four, the students will not only do the activities in written form but also in oral form. While watching the video, the students will produce spoken language as if they were the actors of the video. Here are the activities.

\section{1) Activity 1 (identifying the parts of speech)}

\section{Instructions: Watch the video and answer the questions by typing the answers in the box provided.}

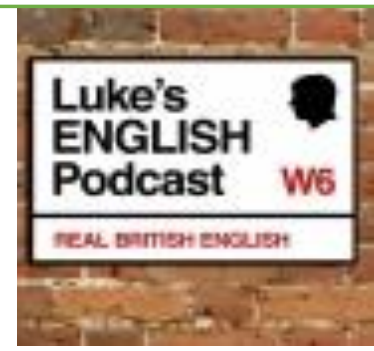

Questions:

1. What are four proper nouns found in opening section?

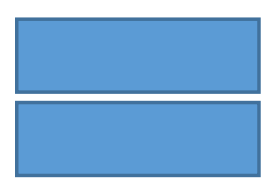




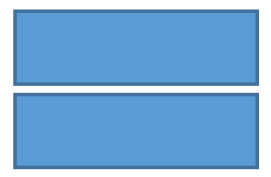

2. What are the words used to describe the best things about London?
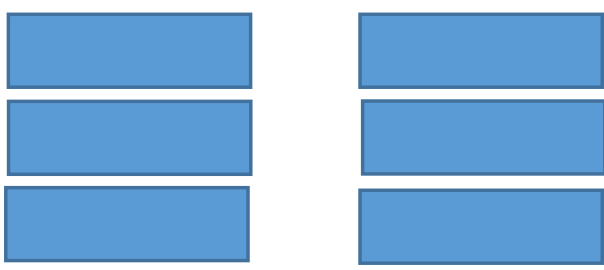

What do you call those words?

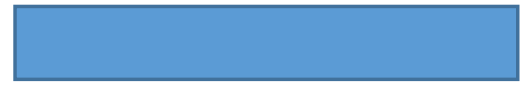

3. How many times did you hear the word "yeah" from the first interviewee?

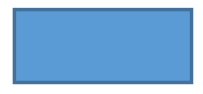

What kinds of part of speech is "yeah"?

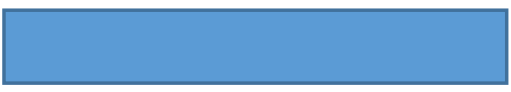

In spoken language "yeah" is called

$$
\text { B }
$$

2) Activity 2 (producing the words)

Instructions: Watch the video and
produce the missing
script by holding
therecord button.

\section{CONCLUSION}

Since the students need to know how to write and speak accurately and fluently, they have to learn grammar. Students' grammar awareness can be nourished through direct explanation (the language usage) and noticing (how the language use in real life). Since the students do not live in English country, the teacher needs to facilatate the students with native country situation by exposing spoken language through authentic material, such as video podcast. Hopefully teaching grammar to the students means teaching students to be able to be in formal and informal situations. Inserting spoken language based on interactive multimedia can promote the students accuracy and fluency on grammar. Further research is needed to see the effect of inserting spoken language based on interactive multimedia on students' grammar mastery.

\section{References}

Al-wossabi, S. A. (2014). Spoken grammar: An urgent necessity in the EFL context. English Language Teaching, 7(6), 19-25. doi:10.5539/elt.v7n6p19

Ampa, A. T. (2015). The implementation of interactive multimedia learning materials in teaching listening skills. English Language Teaching (Online), 8(2), (http://dx.doi.org/10.5539/elt.v8n12p56), 56-62.

Brown, H. D. (2001). Teaching by Principles. (2nd ed). New York: Longman.

Carter, R., \& McCarthy, M. (1995). Introduction to grammar and spoken English.

Chalker, S. (1994). "Pedagogical Grammar". In M. Bygate, A. Tonkyn, \& E. W. (Eds), Grammar and the Language Teacher (pp. 31-44). New York: Prentice Hall.

Costello, V., Youngblood, S. A., \& Youngblood, N. E. (2012). multimedia foundations. Oxford: Focal Press.

Ely, D. (1990). Condition that facilitate the implementation of education technology innovation. Journal of Research on Computing Education, 23(2), 293-305. Retrieved from http://dx.doi.org/10.1080/08886504.1990.10781963

Hamzah, M. I., Rinaldi, \& Razak, K. A. (2014). Multimedia usage among Islamic education lecturers at higher education institution. International Education Studies, 7(13), 157-165. doi:10.5539/ies.v7n13p157

Herrington, J., \& Herrington, A. (1998). Authentic assessment and multimedia: How university responds to a model of authentic assessment. Higher Education Research and Development, 17(3), 305-322.

Hilliard, A. (2014). Spoken grammar and its role in the English language classrooom. English Teaching Forum, 2-13.

Honda, M., \& O'Neil, W. (2008). Thinking linguistically: A scientific approach to language. Malden, MA: Blackwell Publishing.

Horowitz, R., \& Samuels, S. (1987). Comprehending oral and written language. Bingley, England: Emerald Group.

Ivers, K. S., \& Barron, A. E. (2010). Multimedia projects in education: Designing, producing and assesing. California: ABC-CLIO, LLC.

Jingjit, M. (2015). The effects of multimedia learning on Thai primary pupils' achievement in size and depth of vocabulary knowledge. Journal of Education and Practice (Online), 6(32), 72-81. Retrieved from (http:// www.iiste.org).

Joshi, A. (2012). Multimedia: a technique in teaching process in the classrooms. Current World Environment, 7(1), 3336.

Leech, G. (200). Grammar of spoken English: new outcomes of corpus-oriented research. Language Learning, (4), $675-724$. 
Li, Z.-N., \& Drew, M. S. (2004). Fundamentals of multimedia. Australia: Prentice Hall.

Liu, J. (2010). An experimental study on the effectiveness of multimedia in college English teaching. English Teaching Journal (Online), 3(1). Retrieved from (http://www.ccsenet.org/elt), 191-194.

Mayer, R. E. (2001). Multimedia Learning. New York: Cambridge University Press.

Mayer, R. E. (2005). Introduction to multimedia learning. In R. E. Mayer, The Cambridge Handbook of Multimedia Learning (pp. 1-16). Cambridge: Cambridge University Press.

Mayer, R., \& Moreno, R. (2002). Aids to computer-based multimedia Learning. Learning and Instruction, (12), 107-119.

McCarty, M., \& O'Keeffe, A. (2014). Spoken grammar. In M. Celce-Murcia, D. M. Brinton, \& M. A. Snow, Teaching English as a Second or Foreign Language (pp. 271-287). Boston: Heinle.

Newby, T. J., Stepich, D. A., Lehman, J. D., \& Russell, J. D. (2000). Instructional for teaching and learning. New Jersey: Prentice Hall.

Phillips, R. (1997). The developers' handbook to interactive multimedia. London: British Library.

Refnaldi, Ardi, H., \& Tiarina, Y. (2010). Pengembangan materi ajar Listening 1 berbasis multimedia. Padang: Tidak Dipublikasikan.

Refnita, L. (2012). Pengembangan model asesmen mata kuliah English Grammar untuk Program Studi Bahasa Inggris di perguruan tinggi. Disertasi. tidak diterbitkan. Padang: Universtas Negeri Padang.

Roblyer, M. D., \& Doering, A. (2010). Integrating educational technology into teaching (5th Ed). Boston: Allyn dan Bacon.

Ruhlemann, C. (2008). A register approach to teaching conversation: Farewell to Standard English? Apllied Linguistics, 29(4), 672-693.

Schwier, R. A., \& Misanchuk, E. R. (1993). Interactive multimedia instruction. New Jersey: Educational Technology Publications.

Simkins, M., Cole, K., Tavalin, F., \& Means, B. (2002). Increasing Student Learning through Multimedia Projects. Alexandria: Association for Supervision and Curriclum Development.

Siskos, A., \& Antoniou, P. (2005). Effects of multimedia Computer-Assisted Instruction (MCAI) on academic achievement in physical education of Greek primary students. Interactive Educational Multimedia (Online), No 10, (http://www.ub.edu/multimedia/iem), 61-77.

Smaldino, S. E., Russell, J. D., Heinich, R., \& Molenda, M. (2014). Instructional Media and Teachnology for Learning. Ed.10th. New Jersey: Prentice Hall.

Solomon, A. W. (2011). Introduction to multimedia. Columbus: Glencoe/Mc. Grow Hill.

Stenstrom, A. (2004). An introduction to spoken interaction. London: Longman.
Willis, D. (2003). Rules, patterns and words: Grammar and lexis in English language teaching. Cambridge: Cambridge University Press. 